\title{
Analisis Pendapatan Pedagang Kaki Lima Sektor Informal Di Kecamatan Rappocini Kota Makassar
}

\author{
Marhawati \\ Pendidikan Ekonomi Universitas Negeri Makassar \\ Email : marhawati@unm.ac.id
}

\begin{abstract}
Street Vendors are one of the informal sectors that are found in urban areas. The existence of street vendors does not always require formal education and high skills and does not require a large capital. This study aims to determine the factors that affect the income of street vendors in Talasalapang Street, Rappocini Regency, Makassar City. The population in this study was not greater than 100 people, so the census technique was used by taking the overall population of 60 street vendors. The analysis technique used is Multiple Linear Regression using a partial hypothesis test (t-test) and simultaneous ( $F$ test), using SPSS 21. The results showed that capital, business experience, and time allocation of trying to jointly affect street vendors' income. Partially shows that capital and time allocation try to have a positive and significant effect on street vendors 'income, while the experience of trying not to affect street vendors' income on Talasalapang Street, Rappocini Regency, Makassar City.
\end{abstract}

Keywords: Street Vendors; Capital; Length of Business; Time Allocation

\begin{abstract}
Abstrak. Pedagang Kaki Lima merupakan salah satu dari sektor informal yang banyak ditemukan di perkotaan. Keberadaan Pedagang Kaki Lima tidak selalu memerlukan pendidikan formal dan ketrampilan yang tinggi dan tidak mensyaratkan modal yang besar. Penelitian ini bertujuan untuk mengetahui faktor faktor yang memengaruhi pendapatan pedagang kaki lima di Jalan Talasalapang Kecamatan Rappocini Kota Makassar. Jumlah populasi dalam penelitian ini tidak lebih besar dari 100 orang, maka digunakan teknik sensus dengan mengambil secara keseluruhan populasi yaitu sebanyak 60 orang pedagang kaki lima. Teknik analisis yang digunakan adalah Regresi Linier Berganda menggunakan uji hipotesis secara parsial (uji t) dan simultan (uji F), dengan menggunakan SPSS 21. Hasil penelitian menunjukkan bahwa modal, pengalaman berusaha dan alokasi waktu berusaha berpengaruh secara bersama-sama terhadap pendapatan pedagang kaki lima. Secara parsial menunjukkan bahwa modal dan alokasi waktu berusaha berpengaruh positif dan signifikan terhadap pendapatan pedagang kaki lima, sedangkan pengalaman berusaha tidak berpengaruh terhadap pendapatan pedagang kaki lima di Jalan Talasalapang Kecamatan Rappocini Kota Makassar.
\end{abstract}

Kata Kunci: Pedagang Kaki Lima; Modal; Lama Berusaha; Alokasi Waktu Berusaha

\section{PENDAHULUAN}

Pembangunan di wilayah perkotaan dan ketersediaan fasilitas umum yang lebih menarik di wilayah perkotaan, telah menimbulkan arus urbanisasi yang semakin banyak dan menjadi salah satu penyebab permasalahan baru di daerah perkotaan. Urbanisasi yang berlebihan dapat menjadikan kawasan perkotaan menjadi daerah padat penduduk dan menimbulkan permasalahan sosial dan ekonomi (Kuncoro, 2012: 220 - 222), misalnya dalam bidang ketenagaankerjaan. Keterbatasan sektor tenaga kerja formal dalam menampung tenaga kerja menyebabkan para pencari kerja memilih sektor informal sebagai ladang mata pencahariannya. BPS (2018), menyatakan bahwa mayoritas penduduk Indonesia bekerja disektor informal, yakni sebanyak 56,84 persen dari jumlah penyerapan tenaga kerja.

Menurut (Simanjuntak, 2001) usahausaha yang tergolong sektor informal memiliki ciri-ciri sebagai berikut : 1) Unit usahanya berskala kecil; 2) Dagangannya relatif sederhana; 3) Tidak harus ada ijin usaha; 4) 
Mudah jika masuk ke pekerjaan informal ; 5) Penghasilan rendah; 6) Terlihat sedikit relasi terhadap bidang lain; 7) Bidang usaha sektor informal sangat beraneka ragam. Faktor utama dalam meningkatnya pertumbuhan sektor informal adalah karena kurangnya penyerapan tenaga kerja pada sektor formal. Ditambah dengan adanya pertambahan angkatan kerja di perkotaan yang disebabkan oleh migrasi dari desa ke kota. Pesatnya jumlah penduduk yang melakukan migrasi mengalahkan jumlah kesempatan kerja di kota. Akibatnya, terjadi pengangguran di kota-kota besar sehingga memicu munculnya sektor-sektor informal di perkotaan (Fernando, 2016).

Persaingan dalam dunia bisnis khususnya dalam bidang usaha memiliki daya saing yang cukup tinggi. Dalam aktivitas perkotaan yang serba gemerlap, keberadaan Pedagang Kaki Lima terasa terasingkan. Harus diakui bahwa keadaan ini timbul karena adanya ketimpangan sosial dan pembangunan serta pendidikan yang tidak merata. Padahal peran Pedagang Kaki Lima sangatlah penting karena dapat mendatangkan sisi positif pada sektor usaha informal. Pilihan masyarakat untuk bekerja di sektor informal dianggap merupakan langkah terbaik saat menghadapi tekanan ekonomi. Usaha pada sektor informal yang dilakukan oleh masyarakat di sekitar kota. Pilihan masyarakat tersebut dikarenakan bekerja di sektor informal khususnya Pedagang Kaki Lima yang hanya memerlukan modal serta keterampilan yang minim. Pekerjaan sebagai Pedagang Kaki Lima telah dimanfaatkan sebagai pekerjaan utama ataupun sebagai pekerjaan sampingan untuk menambah penghasilan. Keadaan tersebut membuktikan bahwa Pedagang Kaki Lima merupakan salah satu alternatif lapangan pekerjaan untuk mengatasi pengangguran yang ada di perkotaan (Firdausa \& Arianti, 2013).

Pedagang kaki lima merupakan salah satu dari sektor informal yang banyak ditemukan di perkotaan. Pedagang ini sering menggunakan tempat yang digunakan yang menjadi pusat kegiatan umum, seperti di depan toko-toko, trotoar, dekat pusat pendidikan karena menurut mereka tempat- tempat seperti itu adalah tempat yang strategis untuk mereka berdagang. Tidak terkecuali kota Makassar, khususnya Pedangang kaki lima di Jalan Talasalapang yang menjual berbagai jenis barang dagangan seperti makanan, minuman, pulsa, bengkel, assesories, campuran sepatu dan sandal, serta pakaian. Jalan Talasalapang adalah salah satu ruas jalan raya di kota Makassar yang merupakan jalan yang menghubungkan antara jalan Sultan Alauddin menuju kawasan permukiman warga. Di Jalan Talasalapang ini juga terdapat salah satu universitas swasta yaitu Universitas Muhammadiyah Makassar yang mayoritas mahasiswa dan mahasiswinya bertempat tinggal sementara atau kost di sekitar Jalan Talasalapang. Ini merupakan salah satu faktor yang mempengaruhi pendapatan pedagang kaki lima yang berjualan di sepanjang Jalan Talasalapang.

Berdasarkan observasi awal yang dilakukan bahwa pedagang kaki lima yang sudah berjualan sampai empat tahun menyatakan memperoleh pendapatan yang menurut mereka dapat memenuhi kebutuhan hidup, serta bagi pedagang kaki lima yang berjualan satu atau dua tahun juga memperoleh pendapatan, akan tetapi masih terdapat pedagang kaki lima yang tidak bertahan atau tidak berdagang lagi yang disebabkan mengalami kerugian, kekurangan modal dan waktu berdagang yang terlalu sedikit.

Berdasarkan latar belakang penelitian di atas maka yang menjadi rumusan masalah dalam penelitian ini adalah: Apakah Modal, Alokasi Waktu Berusaha dan Pengalaman Berusaha berpengaruh secara parsial dan simultan terhadap pendapatan pedagang kaki lima sektor informal di Jalan Talasalapang Kota Makassar. Penelitian ini dilakukan dengan tujuan sebagai berikut: Untuk mengetahui seberapa besar pengaruh modal, Alokasi Waktu Berusaha dan Pengalaman Berusaha secara parsial dan simultan terhadap pendapatan pedagang kaki lima sektor informal di Jalan Talasalapang Kota Makassar.

\section{METODE PENELITIAN}

\section{Populasi dan Sampel}

Populasi dalam penelitian ini adalah seluruh Pedagang Kaki Lima yang berjualan di sepanjang Jalan Talasalapang yang menjual barang dagangannya sendiri dan merupakan sebagai mata pencaharian pokok sehari hari sebanyak 60 orang. Dalam menentukan sampel kita dapat mengacu pada pendapat yang dikemukakan oleh Arikunto (2013:104) menyatakan bahwa: "jika jumlah populasinya kurang dari 100 orang, maka jumlah sampelnya diambil keseluruhan, tetapi jika populasinya lebih besar dari 100 orang, maka bisa diambil 
$10-15 \%$ atau $20-25 \%$ dari jumlah populasinya. Jumlah populasi dalam penelitian ini tidak lebih besar dari 100 orang responden, maka digunakan teknik sensus dengan mengambil secara keseluruhan populasi yaitu sebanyak 60 orang pedagang kaki lima di Jalan Talasalapang Kota Makassar

\section{Teknik Analisis Data}

\section{Analisis Regresi Linear Berganda}

Analisis data yang digunakan dalam penelitian ini adalah Regresi Linier Berganda, hal tersebut dikarenakan penggunaan variabel yang lebih dari satu (multivariable) dengan rumus sebagai berikut : $\mathrm{Y}=\mathrm{F}(\mathrm{X} 1, \mathrm{X} 2, \mathrm{X} 3)$. Kemudian di sesuaikan dengan kebutuhan penelitian dengan bantuan program SPSS 21 dan diformulasikan sesuai dengan rumus persamaan oleh Gujarati (2003:28) sebagai berikut :

$\mathrm{Y}=\beta 0+\beta 1 \mathrm{X} 1+\beta 2 \mathrm{X} 2+\beta 3 \mathrm{X} 3+\mathrm{e}$

Dimana:

$\mathrm{Y}=$ Pendapatan Responden (pedagang kaki lima)

$\alpha=$ Konstanta

$\mathrm{X} 1=$ Modal $(\mathrm{Rp})$

$\mathrm{X} 2=$ Pengalaman Berusaha (Tahun)

X3 = Alokasi Waktu Berusaha (jam)

$\mathrm{B} 1, \beta 2, \beta 3,=$ Koefisien Regresi

$\mu=$ Error Terms/ Kesalahan Pengganggu

\section{Pengujian Hipotesis}

Uji statistik dilakukan untuk mengetahui besarnya masing-masing koefisien dari variabel-variabel bebas baik secara parsial maupun secara bersama terhadap variabel terikat yaitu dengan menggunakan uji parsial (uji-t), uji secara serentak (uji-F) dan koefisien determinasi berganda (R2).

\section{Koefisien Determinasi (R2)}

R2 bertujuan untuk mengetahui seberapa jauh variasi variabel independen dapat menerangkan dengan baik variasi variabel dependen. Konsep OLS adalah meminimumkan residual, sehingga diperoleh korelasi yang tinggi antara variabel dependen dan variabel independen. Nilai R2 yang sempurna dapat dijelaskan sepenuhnya oleh variabel independen yang dimasukkan dalam model. Dimana $0<\mathrm{R} 2<1$ sehingga kesimpulan yang dapat diambil adalah

- Nilai R2 yang lebih kecil atau mendekati nol, berarti kemampuan variabel-variabel bebas dalam menjelaskan variasi variabel tidak bebas sangat terbatas.

- Nilai R2 yang mendekati satu, berarti variabel-variabel bebas memberikan hampir semua informasi yang dibutuhkan untuk memprediksi variasi variabel tidak bebas.

Kriteria pengujian :

1. Apabila nilai R2 mendekati satu maka pengaruh variabel bebas terhadap variabel terikat adalah positif, artinya apabila ada kenaikan dalam variabel bebas akan menyebabkan kenaikkan pada variabel terikat.

2. Apabila nilai R2 mendekati nol maka pengaruh variabel bebas terhadap variabel terikat adalah lemah atau tidak ada hubungan, artinya apabila ada kenaikan atau penurunan pada variabel bebas tidak akan menyebabkan kenaikan pada variabel terikat.

3. Apabila nilai R2 mendekati minus maka pengaruh variabel bebas terhadap variabel terikat adalah sempurna dan negatif, artinya apabila ada kenaikan variabel bebas akan menyebabkan penurunan pada variabel terikat.

\section{Pengujian Secara Bersama-sama (Uji F)}

Uji $F$ pada dasarnya menunjukkan apakah semua variabel independen yang dimasukkan dalam model mempunyai pengaruh secara bersama-sama terhadap variabel dependen.

Hipotesisnya adalah:

H0 : $\beta 1=\beta 2=\beta 3=0$, semua variabel bebas tidak mempengaruhi variabel terikat secara simultan dengan signifikan.

Ha : $\beta 1 \neq \beta 2 \neq \beta 3 \neq 0$, semua variabel bebas mampu mempengaruhi variabel terikat secara simultan dengan signifikan.

Kriteria pengujian:

1. Jika probabilitas $\mathrm{F}$ hitung $\leq \alpha(0.05)$, di mana $\alpha$ merupakan besarnya kesalahan yang ditolerir di dalam pengambilan keputusan maka $\mathrm{H} 0$ ditolak dan $\mathrm{H} 1$ diterima.

2. Jika probabilitas F hitung $>\alpha(0.05)$, di mana $\alpha$ merupakan besarnya kesalahan yang ditolerir di dalam pengambilan keputusan maka $\mathrm{H} 0$ diterima dan $\mathrm{H} 1$ ditolak.

\section{Pengujian Secara Parsial (Uji-t)}

Uji statistik $\mathrm{t}$ pada dasarnya menunjukkan seberapa jauh pengaruh satu variabel independen secara individual dalam menerangkan variasi variabel dependen (Imam Ghozali, 2006). Kriteria pengambilan keputusan: 
1. $\mathrm{H} 1-\mathrm{H} 3$ diterima jika $\mathrm{t}$ hitung $>\mathrm{t}$ tabel dan sig $<\alpha=5 \%$

2. H1-H3 tidak dapat diterima jika t hitung $<\mathrm{t}$ tabel dan sig $>\alpha=5 \%$

\section{HASIL DAN PEMBAHASAN}

Tabel 1. Jumlah Pedagang Kaki Lima dan Jenis Jualannyadi Jalan Tallasalapang, Kecamatan Rappocini, Kota Makassar, 2019.

\begin{tabular}{clcc}
\hline No & \multicolumn{1}{c}{ Jenis Jualan /Usaha } & Jumlah $(\mathbf{o r g})$ & Persentase (\%) \\
\hline 1 & Bengkel Motor & 2 & 3,33 \\
2 & Assesoris Handphone & 3 & 5 \\
3 & Es Kelapa Muda & 2 & 3,33 \\
4 & Terang Bulan / Martabak & 3 & 5 \\
5 & Barang Campuran & 6 & 10 \\
6 & Pakaian & 3 & 3,33 \\
7 & Asesories/hiasan & 1 & 1,67 \\
8 & Pulsa & 6 & 10 \\
9 & Café & 2 & 3,33 \\
10 & Boneka & 2 & 3,33 \\
11 & Aneka Minuman dingin & 2 & 3,33 \\
12 & Warung Makan Sari Laut & 5 & 8,33 \\
13 & Warung Kopi & 2 & 3,33 \\
14 & Stiker & 2 & 3,33 \\
15 & Jilbab & 2 & 3,33 \\
16 & Kacamata & 2 & 3,33 \\
17 & Baju/Celana & 5 & 8,33 \\
18 & Aneka Gorengan & 3 & 5 \\
19 & Helm & 2 & 3,33 \\
20 & Sepatu & 3 & 5 \\
21 & Kaos Kaki & 2 & 3,33 \\
\hline & J u m l a h & 60 & 100,00 \\
\hline
\end{tabular}

Sumber : Data Primer,diolah, 2019

Pedagang kaki lima yang berjualan di jalan Talasalapang Kecamatan Rappocini Kota Makassar di dominasi oleh pedagang perempuan yaitu sebanyak 40 orang atau $66,67 \%$, dan laki-laki sebanyak 20 orang atau $33,33 \%$ lebih sedikit dibandingkan dengan pedagang yang berjenis kelamin perempuan, kebanyakan dari mereka selain sebagai ibu rumah tangga mereka juga berdagang untuk membantu menopang ekonomi keluarga.

Modal awal yang digunakan oleh responden mulai dari Rp 500.000 sampai dengan Rp 5.000.000. Pedagang yang menggunakan modal sebesar Rp 500.000 sampai Rp 1.500.000,- sebanyak 22 orang atau $36,67 \%$ untuk dagangan jenis asesories, stiker, pulsa, kacamata, aneka gorengan, kaos kaki, aneka minuman dingin, boneka dan lain-lain. Selanjutnya untuk penggunaan modal sebesar Rp 2.000.000, sampai Rp 3.000.000,- sebanyak 28 orang atau $46,67 \%$ untuk dagangan warung kopi, barang campuran, asesories handphone,

\section{Gambaran Umum Responden}

Adapun jenis jualan dan jumlah pedagang kaki lima yang berjualan di sepanjang jalan Tallasalapang dapat dilihat pada tabel 1 berikut ini. 
Masing-masing individu memiliki karakteristik sendiri-sendiri yang berbeda antara satu sama lain. Karakteristik ini merupakan beberapa aspek yang mempengaruhi ketrampilan pedagang dalam mengelola usahanya. Karakteristik responden dalam kajian ini meliputi berbagai informasi tentang kondisi rikut ini. internalnya antara lain umur, tingkat pendidikan formal, jumlah tanggungan keluarga dan pengalaman dalam berdagang, alokasi waktu yang digunakan untuk berdagang dan pendapatan yang diperoleh. Untuk lebih jelasnya dapat dilihat pada tabel be

Tabel 2. Karakteristik pedagang yang berjualan di Jalan Talasalapang Kecamatan Rappocini Kota Makassar

\begin{tabular}{|c|c|c|c|}
\hline Nomor & Ura i a n & umlah (orang) & Persentase (\%) \\
\hline \multirow[t]{4}{*}{1.} & Umur Pedagang & & \\
\hline & $<30$ tahun & 2 & 3,33 \\
\hline & a. $30-50$ tahun & 33 & 55 \\
\hline & b. $>50$ tahun & 25 & 41,67 \\
\hline \multirow[t]{5}{*}{2.} & Tingkat Pendidikan & & \\
\hline & a. Tamat SD & 22 & 36,67 \\
\hline & b. Tamat SMP & 20 & 33,33 \\
\hline & c. Tamat SLTA & 17 & 28,33 \\
\hline & d. Tamat PT & 1 & 1,67 \\
\hline \multirow[t]{4}{*}{3.} & Jumlah Tanggungan Keluarga & & \\
\hline & a. $<3$ jiwa & 24 & 40 \\
\hline & b. $3-6$ jiwa & 35 & 58,33 \\
\hline & c. $>6$ jiwa & 1 & 1,67 \\
\hline \multirow[t]{4}{*}{4.} & Lama Berusaha/dagang & & \\
\hline & a. $<10$ tahun & 40 & 66,67 \\
\hline & b. $10-15$ tahun & 15 & 25 \\
\hline & c. $>15$ tahun & 5 & 8,33 \\
\hline \multirow[t]{4}{*}{5.} & Alokasi Waktu/Jam Berdagang & & \\
\hline & a. $\quad<8$ jam & 8 & 13,33 \\
\hline & b. $8-10$ jam & 30 & 50 \\
\hline & c. $>10 \mathrm{jam}$ & 22 & 36,67 \\
\hline \multirow[t]{4}{*}{6.} & Pendapatan & & \\
\hline & a. $\quad<\operatorname{Rp} 250.000$ & 25 & 41,67 \\
\hline & b. $\quad \operatorname{Rp} 250.000-\operatorname{Rp} 1000.000$ & 30 & 50 \\
\hline & c. $>\operatorname{Rp} 1.000 .000$ & 5 & 8,33 \\
\hline
\end{tabular}

Sumber : Data Primer, diolah, 2019.

Dari tabel 2 menunjukkan bahwa tingkat umur berpengaruh terhadap produktivitas pedagang karena secara fisik masih memiliki kemampuan yang cukup baik untuk melakukan aktivitas usahanya. Rata-rata responden berumur 41,5 tahun dengan umur minimal 27 tahun dan maksimal 56 tahun. Dari segi umur dapat disimpulkan bahwa pedagang pada umumnya produktif, masih mempunyai fisik dan tenaga yang prima dalam melakukan usaha dagangnya. Dengan usia produktif pedagang diharapkan mampu membaca pasar dan memanfaatkan peluang untuk meningkatkan pendapatannya.

Pendidikan mempunyai peranan penting dalam upaya meningkatkan kecerdasan dan ketrampilan manusia. Tingkat pendidikan juga berpengaruh terhadap keberhasilan dalam mengelola suatu usaha yang digelutinya. Semakin tinggi tingkat pendidikan membuat pedagang semakin responsif dalam menerima dan menerapkan inovasi baru. Dengan demikian dengan meningkatnya pendidikan akan lebih berhasil dalam mengelola usahanya. Dari segi pendidikan formal pedagang sebagian besar $(36,67 \%)$ hanya berpendidikan Sekolah Dasar. Lama pendidikan petani rata-rata 7,56 tahun dengan lama minimal 0 tahun dan maksimal 18 tahun. Pendidikan yang rendah akan mempengaruhi pola pikir pedagang dalam menjalankan kegiatan usahanya dan pengambilan keputusan dalam memasarkan dagangannya. 
Adanya jumlah tanggungan keluarga bagi pedagang akan memberikan motivasi untuk berusaha meningkatkan penghasilan demi menghidupi keluarganya, karena mereka sebagai tulang-punggung keluarga. Jumlah tanggungan keluarga biasanya mempengaruhi pedagang sebagai kepala rumah tangga agar giat dalam berusaha supaya dapat memenuhi kebutuhan rumah tangganya Jumlah tanggungan keluarga terbanyak 3 sampai 6 orang berjumlah 35 orang atau $58,33 \%$.

Pengalaman atau jangka waktu pengusaha dalam melakukan usahanya memberikan pengaruh penting bagi pemilihan strategi dan cara melakukan usahanya. Pengusaha yang lebih lama dalam melakukan usahanya akan memiliki strategi yang lebih matang dan tepat dalam mengelola, memproduksi dan memasarkan produknya. Karena pengusaha yang memiliki jam terbang tinggi di dalam usahanya akan memiliki pengalaman, pengetahuan serta mampu mengambil keputusan dalam setiap kondisi dan keadaan. Selain itu, pengusaha dengan pengalaman dan lama usaha yang lebih banyak, secara tidak langsung akan mendapatkan jaringan atau koneksi yang luas yang berguna dalam memasarkan produknya. Pengalaman usaha seseorang dapat diketahui dengan melihat jangka waktu atau masa kerja seseorang dalam menekuni suatu pekerjaan tertentu. Semakin lama seseorang melakukan usaha atau kegiatan, maka pengalamannya akan semakin bertambah. Pengalaman berdagang atau berusaha terbanyak 40 Orang $(66,67 \%)$ yaitu antara 1sampai 10 tahun.

Berikut dapat diketahui mengenai jam kerja atau jam berdagang setiap harinya. Pedagang kaki lima yang berdagang kurang dari 8 jam secara umum mulai dari pukul 07.00 sampai pukul 13.00 sebanyak 8.orang atau $13,33 \%$, kemudian pedagang kaki lima yang berdagang 8 sampai 10 jam mulai buka dari pukul 07.00 sampai 17.00 sebanyak 30 orang atau $50 \%$. Selanjutnya pedagang yang buka selama 17 jam mulai pukul 07.00 sampai pukul 24.00 .
Pendapatan setiap hari yang diperoleh pedagang kaki lima berfluktuasi, tergantung pada waktu-waktu tertentu. Pada hari-hari biasa, tingkat pendapatan mereka biasa saja, akan tetapi pada waktu hari libur, hari raya, tingkat pendapatan mereka juga meningkat. Pedapatan perhari pada pedagang kaki lima di jalan Tallasalapang berdasarkan hasil penelitian diketahui bahwa pendapatan terendah adalah sebesar Rp 100.000 dan pendapatan yang tertinggi adalahRp 1.500.000. pendapatan terendah tersebut di peroleh pedagang kaki lima untuk jenis dagangan kaos kaki, kacamata, stiker, asesories/hiasan, kemudian pendapatan tertinggi diperoleh pedagang kaki lima untuk jenis makanan dan minuman.

\section{Pembahasan \\ Faktor-faktor yang Memengaruhi Pendapatan Pedagang Kaki Lima}

Metode analisis data yang digunakan dalam penelitian ini adalah metode analisis regresi linier berganda. Untuk mengetahui tingkat signifikan dari masing-masing koefisien regresi variabel independen (variabel bebas) terhadap variabel dependen(variabel terikat) maka menggunakan uji satistik diantaranya uji $\mathrm{F}$, uji t, dan uji R2. Dalam mempermudah pengujiannya peneliti menggunakan software bantuan berupa program SPSS 21 for windows.

\section{Uji Prasyarat Analisis}

Uji Multikolinearitas

Jika ada korelasi yang tinggi diantara variabel-variabel bebasnya, maka hubungan antara variabel bebas dengan variabel terikatnya menjadi terganggu sehingga model regresi yang diperoleh tidak valid. Dari hasil uji multikolinieritas diketahui bahwa masingmasing variabel bebas memiliki nilai toleran lebih dari 0,1 dan VIF lebih kecil dari 10. Sehingga dapat disimpulkan bahwa tidak terjadi multikolinieritas. Hasil uji multikolinieritas secara ringkas disajikan dalam tabel berikut:

Tabel 3. Uji Multikolinearitas Data Pedagang Kaki Lima di Jalan Talasalapang Kota Makassar.

\begin{tabular}{lcclc}
\hline \multicolumn{1}{c}{ Variabel bebas } & \multicolumn{2}{c}{ Colleniarity Statistic } & \multicolumn{2}{c}{ Keterangan } \\
& Tolerance & VIF & \\
\hline Modal (X1) & 0,541 & 1,849 & Tidak & Terjadi \\
Lama Usaha (X2) & 0,499 & 2,003 & Multikolinearitas \\
Alokasi Waktu Usaha (X3) & 0,407 & 2,457 & & \\
\hline
\end{tabular}

Sumber : Data Primer,diolah 2019. 
Uji Normalitas

Suatu data dikatakan berdistribusi normal pada taraf signifikan 5\% jika nilai Asymp. Sig lebih dari 0,05. Berdasarkan perhitungan dengan SPSS 21 for windows, didapat nilai signifikan variabel modal 0,078 , nilai signifikan variabel lama berusaha 0,145 , nilai signifikan alokasi waktu usaha 0,074 dan nilai signifikan pendapatan 0,192. Nilai Asymp. Sig dari ketiga variabel tersebut memiliki nilai diatas 0,05 maka distribusi data dari masing masing variabel dikatakan normal.

\section{Uji Hipotesis}

Analisis regresi berganda digunakan untuk mengetahui pengaruh variabel Modal (X1), Pengalaman Berusaha (X2), Alokasi waktu Berusaha (X3), terhadap Pendapatan Pedagang Kaki Lima (Y). Rangkuman hasil analisis regresi dapat dilihat pada tabel berikut:

Tabel 4 Analisis Faktor-Faktor Yang Memengaruhi Pendapatan Pedagang Kaki Lima di Jalan Talasalapang Kecamatan Rappocini Kota Makassar, 2019.

\begin{tabular}{llcccc}
\hline \multicolumn{1}{c}{ Variable } & $\mathrm{B}$ & Std. Error & $\mathrm{T}$ & Sig. \\
\hline 1. & Modal & 0,819 & 0,146 & 5,609 &, 000 \\
2. Pengalaman Berusaha & $-0,158$ & 0,081 & $-1,933$ &, 059 \\
3. Alokasi Waktu Berusaha & 0,280 & 0,117 & 2,400 &, 020
\end{tabular}

Konstanta

F Hitung

Sig

R Square

0,626

$\mathrm{N}$

Sumber: Data primer diolah, 2019

Berdasarkan tabel 4 maka bentuk persamaan regresi linear berganda yaitu:

$\mathrm{Y}=2,523+0,819 \mathrm{X} 1-0,158 \mathrm{X} 2+0,280 \mathrm{X} 3$

Hasil persamaan regresi tersebut dapat dijelaskan sebagai berikut :

1. Konstanta sebesar 2,523 artinya jika modal (X1), pengalaman berusaha (X2), alokasi waktu berusaha (X3) sama dengan nol (0) maka pendapatan akan mengalami peningkatan sebesar 2,523.

2. Koefisien regresi X1 (modal) sebesar 0,819 , menunjukkan pengaruh modal bernilai positif, hal ini berarti bahwa setiap ada penambahan modal sebesar satu rupiah maka pendapatan pedagang kaki lima akan meningkat sebesar 0.819 .

3. Koefisien regresi X2 (pengalaman berusaha) sebesar -0,158, menunjukkan pengaruh penglaman berusaha bernilai negatif, hal ini berarti bahwa pengalaman berusaha ditambah sebesar satu tahun maka akan menyebabkan penurunan pendapatan pedagang kaki lima sebesar 0.158 .

4. Koefisien regresi X3 (alokasi waktu berusaha) sebesar 0,280, menunjukkan pengaruh alokasi waktu berusaha positif, hal ini berarti setiap ada peningkatan alokasi waktuber usaha satu jam, maka pendapatan pedagang kaki lima akan meningkat sebesar 0.280 .

\section{Uji F}

Uji $F$ menunjukkan bahwa nilai $F$ hitung sebesar 26,731dengan signifikansi 0,000 jauh lebih kecil dari taraf signifikansi yang digunakan dalam penelitian ini yaitu 0,05 atau $5 \%$. Hal ini menunjukkan bahwa modal, pengalaman berusaha, alokasi waktu berusaha secara simultan mempunyai pengaruh yang signifikan terhadap pendapatan pedagang kaki lima di Jalan Talasalapang Kecamatan Rappocini Kota Makassar. Untuk mengetahui variabel mana saja yang mempunyai pengaruh yang positif terhadap pendapatan pedagang kaki lima di Jalan Talasalapang Kecamatan Rappocini Kota Makassar maka dilakukan Uji t.

\section{Uji T}

1. Modal

Variabel modal berpengaruh positif dan signifikan terhadap pendapatan pedagang kaki 
lima di Jalan Talasalapang Kecamatan Rappocini Kota Makassar, hal ini ditunjukkan nilai $\mathrm{t}$ hitung sebesar 5,609 dengan nilai signifikan 0,000 jauh lebih kecil dari taraf siginifikan yang digunakan yaitu 0,05 . Dengan tersedianya modal memungkinkan bagi pedagang untuk menyediakan berbagai alternatif kebutuhan konsumen baik dari sisi kuantitas maupun kualitasnya. Hasil penelitian ini sejalan dengan penelitian dari Sutrisno (2005) Fitria (2014), Muryati (2015), Antara (2016), Firdausa (2013), Efendi (2003), Atun (2016), bahwa modal akan mempengaruhi pendapatan para PKL/ pengusaha. Semakin banyak modal yang digunakan maka semakin banyak pendapatan yang diperoleh.

\section{Pengalaman Berusaha}

Variabel pengalaman berusaha berpengaruh negatif dan tidak signifikan terhadap pendapatan pedagang kaki lima di Jalan Talasalapang Kecamatan Rappocini Kota Makassar, hal ini ditunjukkan nilai t hitung sebesar -1,933 dengan nilai signifikan 0,06 jauh lebih besar dari taraf siginifikan yang digunakan yaitu 0,05. Hal ini dikarenakan Pedagang Kaki Lima merupakan salah satu jenis usaha sektor informal. Dalam sektor formal, dikenal istilah mengenai tingkatan, golongan, atau grade dalam bekerja. Sehingga, semakin lama orang bekerja jenis usaha tersebut maka semakin tinggi pula tingkatan, golongan atau grade seseorang dimana akan meningkatkan pendapatan yang diperolehnya. Namun dalam sektor informal, hampir tidak mengenal istilah tersebut. Dimana dalam sektor informal khususnya Pedagang Kaki Lima, tingkat pendapatan salah satunya ditentukan oleh seberapa banyak seseorang mendapatkan konsumen atau pembeli, tidak ditentukan oleh seberapa lama Pedagang Kaki Lima berusaha pada satu jenis usaha. Hasil penelitian ini sejalan dengan Dinda Suci Sari Dewi (2017) bahwa variable lama usaha tidak berpengaruh positif terhadap pendapatan Pedagang Kaki Lima di Kecamatan Medan Baru Kota Medan.

\section{Alokasi Waktu Berusaha}

Variabel alokasi waktu berusaha berpengaruh positif dan signifikan terhadap pendapatan pedagang kaki lima di Jalan Talasalapang Kecamatan Rappocini Kota Makassar, hal ini ditunjukkan nilai t hitung sebesar 2,400 dengan nilai signifikan 0,020 jauh lebih kecil dari taraf siginifikan yang digunakan yaitu 0,05 . Hal ini dimugkinkan karena dengan semakin lama waktu berjualan tentu membuka peluang bagi konsumen untuk melihat, datang dan membeli barang dagangannya. Temuan ini sesuai dengan penelitian Muryati (2015), Hariningsih (2008), Fitria (2014) dan Adhikari (2017) yang menyatakan bahwa jam kerja berpengaruh secara signifikan terhadap pendapatan pedagang, semakin lama seseorang berdagang akan memiliki lebih banyak waktu untuk berinteraksi dengan pembeli sehingga dapat meningkatkan pendapatan.

\section{Koefisien Determinasi}

Koefisien determinasi pada intinya mengukur seberapa jauh kemampuan model dalam menerangkan variasi variabel dependen. Nilai koefisien determinasi adalah antara nol dan satu. Nilai yang mendekati satu berarti variabel-variabel bebas (modal,pengalaman berusaha, alokasi waktu berusaha) memberikan hampir semua informasi yang dibutuhkan untuk memprediksi variabel terikat. (pendapatan pedagang kaki lima). Untuk lebih jelasnya dapat dilihat pada tabel berikut ini.

Tabel 5 Koefesien Determinasi $\left(\mathrm{R}^{2}\right)$

Model Summary ${ }^{\mathrm{b}}$

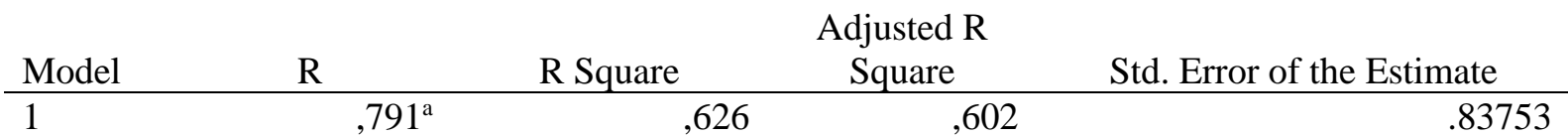

a. Predictors: (Constant), Alokasi Waktu Usaha, Modal, Lama Usaha

b. Dependent Variable: Pendapatan pedagang kaki lima

Sumber: Data primer yang telah diolah, 2019.

Tabel 5 diatas menunjukkan bahwa hasil perhitungan diperoleh nilai koofesien determinasi yang disimbolkan dengan $\mathrm{R}^{2}$ sebesar 0,626 dengan kata lain hal ini menunjukkan bahwa besar persentase variabel pendapatan pedagang kaki lima yang bisa dijelaskan oleh ketiga variabel bebas yaitu modal (X1), pengalaman berusaha (X2), alokasi 
waktu berusaha (X3), sebesar 62,6\%, sedangkan sisanya yaitu sebesar $37,4 \%$ yakni variabel-variabel diluar penelitian.

\section{KESIMPULAN DAN SARAN}

Berdasarkan hasil penelitian dan pembahasan yang dilakukan dapat ditarik beberapa kesimpulan:

1. Faktor produksi modal, lama usaha, alokasi waktu usaha berpengaruh secara simultan (bersama-sama) terhadap pendapatan pedagang kaki lima di Jalan Tallasalapang Kecamatan Rappocini Kota Makassar.

2. Secara parsial, variabel yang berpengaruh signifikan terhadap pendapatan pedagang kaki lima di Jalan Tallasalapang Kecamatan Rappocini Kota Makassar adalah modal dan alokasi waktu berusaha sedangkan variabel yang tidak berpengaruh adalah pengalaman berusaha

\section{SARAN}

1. Untuk meningkatkan pendapatan usaha Pedagang Kaki Lima khususnya di sekitar Jalan Talasalapang Kecamatan Rappocini Kota Makassar maka perlu ditunjang berbagai faktor terutama modal. Diharapkan Bank atau instansi terkait untuk memperbanyak program Kredit Usaha Rakyat (KUR) agar para PKL yang akan memulai usaha dapat melakukan peminjaman modal dengan mudah tanpa persyaratan-persyaratan yang menyulitkan para pedagang dalam meminjam modal.

2. Diharapkan untuk pemerintah memberi dukungan terhadap PKL dengan cara mengadakan pelatihan berwirausaha, dan menyediakan tempat/pasar yang layak agar PKL tidak menggunakan trotoar jalan sehingga tidak menimbulkan kesemrawutan di jalanan.

3. Diharapkan para PKL dapat menambah jam kerja mereka agar pendapatan juga bertambah serta terus berinovasi dan melakukan diferensiasi terhadap produk yang mereka jual agar dapat terus bersaing.

\section{DAFTAR PUSTAKA}

Arikunto.,S. 2013. Prosedur Penelitian : Suatu Pendekatan Praktik. Jakarta: Rineka Cipta.

Christina Menuk S, Tony Susilo Wibowo. 2016. Faktor-faktor Yang Mempengaruhi Pendapatan Pedagang Kaki Lima Studi Kasus PKL di Surabaya, Majalah
Ekonomi _ ISSN No. 1411-9501_Vol. XXI No. 2

Dewi, Dinda Suci Sari. 2017. Faktor-Faktor yang Mempengaruhi Pendapatan Pedagang Kaki Lima di Kota Medan (Studi Kasus: Kecamatan Medan Baru . http://repositori.usu.ac.id

Fernando, Yandhi dan M. Pudjihardjo, SE, 2016. Faktor-Faktor Yang Mempengaruhi Pendapatan Pedagang Kaki Lima (Studi Kasus Di Pasar Besar Kota Malang). Jurnal Universitas Brawijaya.

Firdausa, R. A., \& Arianti, F. 2013. Pengaruh Modal Awal , Lama Usaha, dan Jam

Kerja terhadap Pendapatan Pedagang

Kios di Pasar Bintoro Demak. DIPONEGORO JOURNAL OF ECONOMICS, 2, 1-6.

Ghozali, Imam. (2006). Aplikasi Analisis Multivariate Dengan Program SPSS. Semarang: Badan Penerbit Universitas Diponegoro.

Gujarati, Damordar N. 2007. Dasar-Dasar Ekonometrika Jilid 2. Jakarta: Erlangga.

Hanum, N.2017. Analisis Faktor-faktor Yang Mempengaruhi Pendapatan Pedagang Kaki Lima di Kota Kuala Simpang, Jurnal Samudra Ekonomika, Volume 1, No 1.

I Komang Adi Antara, Luh Putu Aswitari. 2016. Beberapa Faktor Yang Mempengaruhi Pendapatan Pedagang Kaki Lima Di Kecamatan Denpasar Barat. E-Jurnal Ekonomi Pembangunan Universitas Udayana Vol.5, No.11

Kuncoro, M. 2012. Perencanaan Daerah "Bagaimana membangun ekonomi lokal, kota dan kawasan". Jakarta: Salemba Empat.

Muhammad Ammar A, Dijan Rahajuni, Abdul Aziz A, Goro B, 2019. Faktor Yang Mempengaruhi Pendapatan Pedagang Kaki Lima (PKL) di Pasar Sunday Morning Purwokerto. Jurnal Ekonomi, Bisnis, dan Akuntansi (JEBA) Volume 21 Nomor 02

Simanjuntak, P. 2001. Pengantar Ekonomi Sumber Daya Manusia. . Jakarta: LPFEUI 